\title{
Environmental Aspects of Formal and Physical Networking of Polish Settlements in the Context of Reformed Administration
}

\author{
Wiktor Glowacki
}

Institute of Urban Development, Poland

Copyright $(2016$ by authors, all rights reserved. Authors agree that this article remains permanently open access under the terms of the Creative Commons Attribution License 4.0 International License

\begin{abstract}
This article examines the role of Polish unions of municipalities after the reform of territorial self-government in 1999. Before the reform, unions of municipalities used to substitute missing regional level of self-government. After the reform they were likely to disappear because regional and district levels of self-government were introduced. Contrary to these expectations this article suggests that unions of municipalities in Poland still play important role in dealing with some environmental problems.
\end{abstract}

Keywords Local Government, Environment, Union of Municipalities, Regional Reform

\section{Introduction}

Variety of links contacts and interrelations between towns and villages had developed throughout the world long before the term „urban networking” was adopted in order to cover these complex phenomena with one phrase.

Similarly environmental factors have always influenced the attractiveness of land for settlement. Fertile soils provided food, rivers and their valleys provided transport routes, relief provided sites suitable for defence etc. This way environment shaped the settlement network. Initially human settlements developed in places where environmental assets overweighed environmental disadvantages. Gradually increasing population density and economic development have lead to human encroachment on less favourable land. Moreover the very human activity has brought significant and often negative impact on the environment.

Due to political economic and social transformation after 1989 different aspects of local government as well as urban development[8] in Central Europe have been a subject of regional, national and international studies [5] as well as of comparisons between western and eastern European countries [6]

Currently Polish local authorities in cities, towns and villages have to cope with a lot of environmental problems and simultaneously they try to make the best use of scarce environmental assets. Sometimes they join their forces and try to solve problems or to use environmental assets together. The spatial extent of particular environmental conditions is usually different than administrative borders. Therefore the collaboration of local authorities in the domain of environment often takes form of voluntarily established unions or associations of municipalities regardless of existing administrative division of the country. The following paper describes how this form of collaboration looks like in Poland.

The introduction of territorial self-governments in Poland took place in two stages. Local level self-governments were elected first in the very beginning of political transformation. Two higher levels (district called in Polish - powiat and regions called in Polish - wojewodztwo) were established in the end of 90 s together with the whole reform of territorial administration. The role of voluntary unions or associations of local authorities has been different in each stage. In the beginning they developed to some extent as a substitute of missing higher levels of territorial self-governments. Potentially the 1999 administrative reform in Poland could make many unions of municipalities redundant. This article is focused on two basic research questions:

- Does the administrative reform in Poland in 1999 had influenced significantly the role of voluntary unions of municipalities?

- To what extent features of physical environment and the existence of environmental problems influenced the territorial shape and the activity of Polish unions of municipalities?

\section{Administrative Framework of Settlements Networking in Poland}


Two tiers of territorial administration existed in Poland till 1999. These were municipal (local) and regional tiers. These two tiers constituted municipalities (with elected local self-government) and 49 small regions called in Polish województwo headed by representatives of the central government called wojewoda.

However several reasons contributed to the fact that this system was more complicated than it apparently looked. Namely district administrative authorities operating on territorial units consisting of several municipalities existed between the local (municipal) and regional level. Moreover many special administrative bodies e.g. police, courts, fire brigades, sanitary inspectorate had they units operating on territories of various size bigger than a municipality and smaller than a region. There were about 40 branches of such special administration. The number of territorial units within branches varied from 150 to 450 . Furthermore the regional level of administration was also complicated. Apart from the administration headed by the head of the region (wojewoda) regional units of the special administration (the same 40 branches) had been operating on the same level being subordinated directly to their ministries not to the head of the region. To make matter more complicated there were institutions operating on territorial units covering areas larger than a region and their borders had sometimes crossed regional borders [1].

So before 1999 democratic elected bodies existed only at the very top of the system (the parliament) and on the very bottom (municipal councils). All institutions working in between were somehow subordinated to the central government. Regional assemblies of representatives of municipalities performed mainly advisory roles for heads of regions.

The critical assessment of this system was a point of departure for the concept of the administrative reform in Poland, which took place in 1999.

As a result of this reform the three-tier administrative system has been introduced starting from 1999:

- Municipality - called in Polish gmina (this level had existed already before the reform)

- District - called in Polish powiat

- Region - called in Polish województwo

The election of district and regional councils took place in September 1998. So two new mezo-level self-governments could start their activity from 1999. Final number of regions was 16. The largest region (mazowieckie) covered about $12 \%$ of the country area and was inhabited by $13.1 \%$ of country population whereas the smallest one (opolskie) covered only $3 \%$ of the country area with only about $3 \%$ of country population. Few small modifications have been made since the reform and in 2007 there are still the same 16 regions. 7 new districts were established in 2002 and next year one district was abolished. So in 2007 there are 379 districts. The number of municipalities amounts to 2478 . [14]

It is worthy to know that after the reform there are two types of administration on regional level - governmental and self-governmental. The head of regional governmental administration is called in Polish wojewoda (sometimes this word is translated into English as voivod). The chairman of regional self-government is called in Polish marszałek (often translated into English as marshal). Governmental administration is mainly responsible for safety, order and for the obedience of national law whereas self-governmental administration is responsible for broadly understood development of the region.

Boundaries of Polish self-governmental regions are shown on the map 1.

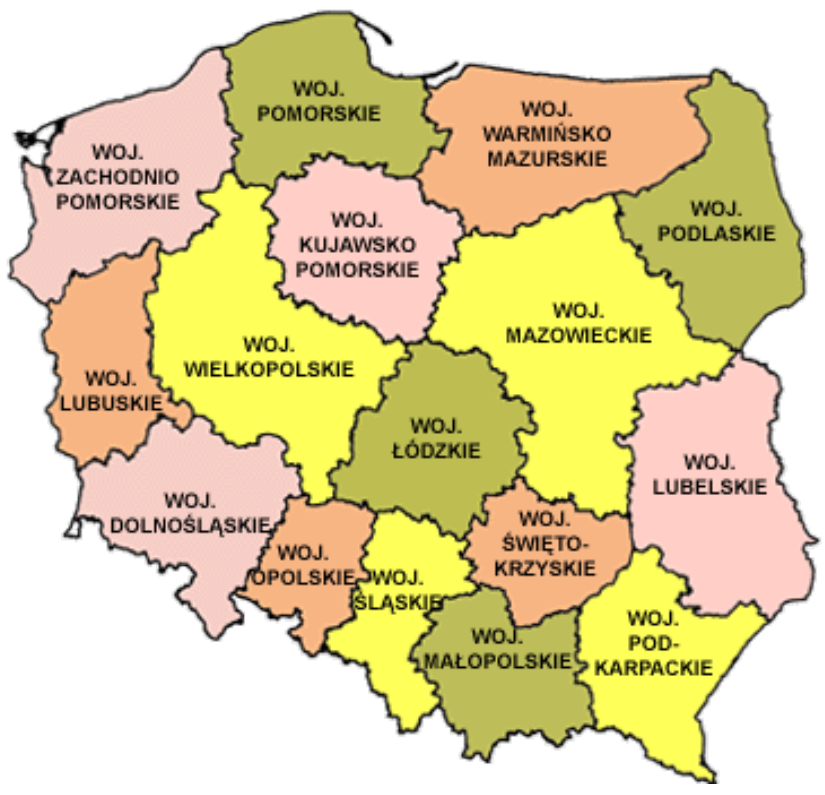

Map 1. Polish self-governmental regions

Source: Map of the Ministry of Interior and Administration

\section{Distribution of Competencies in the Domain of Environment and Natural Resources}

Environmental protection is often perceived as one of integrative functions of the state because its aim is to secure indispensable conditions for life and functioning of the society as a whole [2]. In a broader sense the protection of the environment may be understood as a set of activities aimed at the maintenance of natural backgrounds of human existence including care of all elements of these backgrounds not always directly influencing conditions of human life. This function is performed by almost all states in the world regardless of their wealth and political system. However the extent to which environmental needs of the society are met depends heavily on these factors.

The protection of the environment has been recognized in Polish constitution as one of basic tasks of the state. [9] Moreover the constitution says that this task should be performed in accordance with the rules of the sustainable 
development. This statement implies that environmental protection understood as ecological safety of inhabitants and the natural balance of the environment is a task of both kinds of public administration governmental and self-governmental. One can distinguish three groups of tasks of public administration in the domain of environmental protection:

- Executive tasks - i.e. activities that have direct influence of the quality of the environment. It encompasses mainly the protection against environmentally harmful effects of the everyday life of the community. E.g. sewage management and household waste management.

- Regulatory (distributive) tasks - It encompasses formulating legal conditions of other entities whose activities have significant impact on the environment as well as establishing allowed limits of the use of natural resources by other entities (including the level of emissions) and imposing on them some duties related to the environmental protection. Before the reform these tasks were mainly in hands of governmental regional administration.

- Monitoring, supervisory tasks - are tasks related to the monitoring of the quality of the environment. It includes also the control over obeying environmental regulations by other entities.

As far as the first group of tasks is concerned they are mainly within the competence of the municipality. It is responsible for the construction of sewage treatment plants and networks of sewers as well as for the management of solid household waste. However the actual implementation of these tasks often requires coordination on a bit higher level due to geographical features of the environment (e.g. sewage management in the whole catchments area of the river) or due to economic reasons (the construction of environmentally safe waste disposal sites is expensive therefore it's better to build one such site that would serve several municipalities)

As regards the second group of tasks the division of competencies can be characterized as de-concentration rather than decentralization because the bulk of competencies has been given to the head of the district however not as a task of self-government but as a task of governmental administration. It means that the head of the district (starosta) acts in this domain under the supervision of the governmental administration.

The distribution of environmental competencies between regional and district authorities is complicated due to wide range of environmental issues concerned. As regards activities that have significant environmental impact regulatory tasks of administration are largely encompassed in EIA procedure. For the purpose of EIA procedure two sorts of undertakings which are likely to have significant environmental impact have been distinguished in the act "on categories of undertakings which may significantly affect the environment and on detailed conditions related to qualifying the undertaking for the preparation of EIA report" from 2004. [12] Undertakings that are expected to have more severe environmental impact belong to the first category. The EIA report is obligatory for each of them. The second category encompasses other undertakings of less significant environmental impact. EIA report may be required for them. Decision on making EIA reports remains in hands of the body which issues the decision on the undertaking concerned.

Within the EIA procedure (according to Environmental Protection Law from 2001 with later amendments [4]) the head of the district gives his/her opinion about the necessity EIA report for undertakings from the second category. Moreover all bodies issuing decisions on environmental conditions of development implementation are obliged to agree the contents of the decision with the head of district. Competencies of the head of regional governmental administration (wojewoda) are limited to undertakings from the first of the above-described categories.

Apart from EIA procedure head of the district approves conditions of land reclamation as well as he/she decides on the allowed noise level around industrial plants. As regards installation and facilities that are likely to have negative impact on the environment the head of the district receives results of emissions measurements (if these are important) and he/she may oblige the user of the installation to make such measurements in specific time. He/she must be also notified about any such installation even if it does not require emission permit. If needed the head of the district is entitled to impose specific conditions on the use of these installations as well as he/she decides on doing their environmental audits. In case of emissions from roads, railways, tramlines ports and airports the head of the district may oblige its manager to measure the level of emissions in specific time. Permissions for the introduction of substances or energies to the environment are also in his/her hands. If any user of environmental resources causes environmental damage he/she may oblige him to restore the state of the environment or (if it is impossible) to impose a fine, which should be paid to municipal environmental fund.

Another set of competencies is related to the protection of agricultural land and forests. Fertility of soils and ownership of forests are key criteria for the distribution of decisive power in case of conversion of agricultural land or forest into other use. As the fertility of soils in Poland is ranked from I to VI classes the minister of agriculture decides on the conversion of best soils (classes I - III) and state owned forests whereas the head of the region gives permission for the conversion of medium quality soils (class IV) and private forests. The municipality may convert into other use the poorest agricultural land (classes V and VI) without the permission of any other body. District level has no power in this field.

Nature protection is another field where competencies are distributed among different tiers of administration. The establishment of national parks and Nature 2000 areas is in the competence of the state i.e. the council of ministries and 
the minister of environment respectively. Other natural protected areas may be established by the head of regional governmental administration (wojewoda). Municipality is also entitled to establish some protected natural areas of minor importance.

As regards environmental monitoring and control Environmental Inspection had formerly performed it - a sort of sectoral administration subordinated to the Ministry of the Environment. After the reform this Inspections has been integrated into governmental regional administration. Regional Inspectors of Environmental Protection have a right to decide about stopping activities that cause environmental damage or exceed the allowed level of emission however every such decision must be agreed with the head of the governmental administration in the region or with the head of the district according to the above described general division of regulatory competencies.

All units of territorial self-governments in Poland are obliged by the Environmental Protection Law [10] to prepare their programmes of environmental protection in order to implement the national environmental policy. No deadline for making these programmes has been specified neither any specific punishment have been fixed for those who do not prepare such a programme. Therefore the preparation of these programmes took quite a long time. However, now Polish municipalities usually have them elaborated and approved by municipal councils.

Some competencies of territorial self-governments in relations to specific components of the environment and specific kinds of natural resources are difficult to the equal distribution due to the very nature of the environment. Water resources are managed on strategic level by Regional Water Boards that have not been fully integrated in the reformed administrative system because their boundaries are based mainly on watersheds. The main legal instrument for the water management is called "Conditions of the Use of Water from the Catchments Area". These documents are approved by the Ministry of the Environment and must be agreed with regional assemblies of regions in which the catchments area is located. Moreover other units of the territorial self-government in the area have a right to give their opinion about the proposed conditions. The permissions for the extraction of mineral resources is mainly within the competence of the Ministry of the Environment, the head of the regional governmental administration (wojewoda) gives permissions for the extraction of common mineral resources (defined in the Mining and Geological Law), The head of the district is entitled to give such a permission provided the area of the extraction works does not exceed 2 hectares and the yearly yield does not exceed $10000 \mathrm{~m}^{3}$.

Waste management competencies have been divided between the district and regional governmental administration in accordance with the general division of regulatory competencies. The head of the governmental regional administration makes decisions related to the production of waste in objects that are particularly harmful to the environment whereas all other decisions related to the waste production within the competence of the head of the district. The regional self-government has taken over from the governmental administration the competence to fix payments to be paid for the storage of waste by its producers.

All units of the territorial self-government need financial resources in order to perform their tasks related to the environmental protection. The collection and distribution of money for the implementation of environmental tasks is carried out in Poland by means of institutions called Environmental Protection and Water Management Funds. General rules of their management are included in the Environmental Protection Law from 2001.

There have been four levels of such funds in Poland since the beginning of 1999: National, Regional, District, and Municipal Environmental Protection and Water Management Funds. The two first are functioning as separate legal entities whereas municipal and district funds are targeted parts of municipal and district budgets. The financial management in all funds should be run in accordance with yearly plans of incomes and expenses. These plans are to be approved by supervisory boards of national and regional funds or by district and municipal councils in case of municipal and district funds.

Payments for the use of environmental resources and fines paid for breaking rules of this use are main sources of incomes for Environmental Protection and Water Management Funds. The distribution of incomes among environmental funds is shown in the table below:

Table 1. Shares of Environmental Protection and Water Management Funds in sources of income

\begin{tabular}{|l|l|l|l|l|}
\hline SOURCES OF INCOME & $\begin{array}{l}\text { MUNICIPAL } \\
\text { FUND }\end{array}$ & DISTRICT FUND & REGIONAL FUND & NATIONAL FUND \\
\hline $\begin{array}{l}\text { Payments for the removal of trees and } \\
\text { bushes }\end{array}$ & $100 \%$ & $10 \%$ & $\begin{array}{l}65 \% \text { of the } \\
\text { remaining } 40 \%\end{array}$ & $\begin{array}{l}35 \% \text { of the } \\
\text { remaining } 40 \%\end{array}$ \\
\hline $\begin{array}{l}\text { Payments for the storage of waste and } \\
\text { fines for inappropriate storage of waste }\end{array}$ & $50 \%$ & $10 \%$ & $\begin{array}{l}65 \% \text { of the } \\
\text { remaining } 70 \%\end{array}$ & $\begin{array}{l}35 \% \text { of the } \\
\text { remaining } 70 \%\end{array}$ \\
\hline $\begin{array}{l}\text { Other payments for the use of } \\
\text { environmental resources and fines for } \\
\text { braking rules of the use of these } \\
\text { resources }\end{array}$ & $20 \%$ & &
\end{tabular}

Source: Environmental Protection Law [10] 
It is worthy of mentioning that the national fund has also several other sources of incomes. These are payments paid on the basis of specific regulations set in the environmental law as well as in a few other legal acts. Namely geological law, water law and energetic law. Money from these additional sources may be spent only on specific purposes listed in the environmental law.

Legal regulations contain upper limit of the income of the municipal and district funds. They cannot exceed more than 10 times the average national level of this income per capita from the previous year. The surplus should be passed over to the regional fund. The collection and re-distribution of income is the responsibility of the board of the region and the regional environmental inspector. They run separate bank accounts and make transfers in specified deadlines.

Main directions of the allocation of all funds are also listed in the environmental law. For the purpose of this paper aims of municipal funds are important. These are:

- Environmental education and promotion of environmentally friendly activities and rules of sustainable development;

- Support for national environmental monitoring

- Support for other systems of environmental control measurements and research as well as measurements systems of the use of water and heat;

- Support for systems of data collection and data processing related to the access to environmental information;

- Modernization and investments in the field of environmental protection and water management including flood protection and small water retention;

- Undertakings related to the nature protection including the establishment and the maintenance of green areas woodlots and parks;

- Undertakings related to waste management and to the protection of earth's surface;

- Undertakings related to air protection;

- Undertakings related to water protection;

- Children health prevention in areas where environmental standards are broken;

- Support for the use of local renewable sources of energy and the assistance in the introduction of environmentally friendly energy media;

- Support for environmentally friendly transport;

- Activities in the field of organic farming directly influencing the state of soil water and air, especially in organic farms in protected natural areas;

- Other tasks defined by the municipal council which serve the environment protection and water management and which result from the rule of sustainable development; including environmental protection programmes.

\section{Legal Framework for Settlements Networking in Poland}

Polish municipalities have been entitled to collaborate among themselves from the very beginning of the political transformation in Poland. The first union of municipalities was registered on $5^{\text {th }}$ October 1990. It was the Municipal Union for the construction of gas network with the headquarter in Stryszawa. It encompassed 12 municipalities situated in Beskidy Mountains in southern Poland. This way physical and formal networking of Polish settlements interweave from the outset of current local self-governments.

The act on municipal self-government from $8^{\text {th }}$ March 1990 [11] provides the legal framework for formal networking of municipalities. According to these regulations Polish municipalities may form two sorts of organizations: inter-municipal unions (called shortly municipal unions) and associations of municipalities. Moreover it is possible to make inter-municipal agreements according to which one municipality may perform some task of public administration for the other one.

Municipalities form municipal unions in order to perform jointly municipal public tasks. The union is created on the basis of decisions of councils of all member municipalities. It is required that each municipal council approves the statute of the union. The municipal union is a legal entity and it performs public tasks on behalf of itself. It takes over its duties and rights from member municipalities when the statute of the union is published. Indispensable elements of each statute are:

- The name and the seat of the union,

- Members and period of activity

- Tasks of the union

- Bodies of the union their structure, competencies and procedures,

- Rules for the use of unions properties and facilities,

- Rules for sharing costs of union's activity,

- Accession and leaving rules

- Rules for the dissolution of the union

- Other rules regulating collaboration.

The union's assembly is a decisive and controlling body of the union. It consists of all mayors of all member municipalities. There may be other representative of the municipality in the assembly if the mayor puts forward another candidate, which then is approved by the municipal council. If the statutory regulations allocate to one municipality more than one vote in the assembly the municipal council nominates additional representatives to the assembly. Within competencies commissioned to the union the assembly plays the role similar to the municipal council. The board of the union is its executive body elected by the assembly. If the statute of the union does not say otherwise, up to one third of the board members may be elected from outside of the assembly.

It is also worthy to know that there are some obligatory unions of municipalities established on the basis of separate legal acts.

Associations of municipalities are established in order to support the idea of territorial self-government or in order to 
defend a common interest of municipalities. Not only municipalities but also other units of territorial self-governments may join such associations i.e. districts (powiat) or regions (wojewodztwo). The minimal number of association members is 3 . The national law on associations and the statute of the particular association regulate more precisely their activities. There are much less municipal associations than municipal unions. As there are different approaches to common interests municipal associations also differ among themselves. Some of them are organized on regional basis i.e. they associate municipalities from a particular regions whereas other were established to defend interests of municipalities which have some common characteristics e.g. the association of mining municipalities.

Polish municipalities may also participate in international forms of settlements networking. These forms are usually partnerships of municipalities, twin cities as well as euro-regions. Separate legal acts regulate rules of the accession of Polish municipalities to international organizations of local and regional communities.

Out of many possible forms of formal networking of settlements municipal unions are most relevant to the subject of this paper for several reasons. The most obvious reason is that municipal unions are the most common form of formal networking in Poland. Furthermore municipal unions are usually territorially contingent so they are usually placed in particular physical environmental conditions. They have also clearly defined competencies and as a consequence of this, aims of their activities are relatively well specified. Therefore the subsequent part of the paper is focused mainly on municipal unions in Poland

\section{Development of Municipal Unions in Poland 1990-2007}

The introduction of local democratically elected self-governments was one of the first steps of political transformation in Poland after 1989 events. The act on municipal self-government was adopted on $8^{\text {th }}$ March 1990 and first local election took place in the same year. Municipalities realized the need for collaboration very early so the process of formal registration of municipal unions started from the very beginning of the activity of democratic local self-governments.

The following table presents the pace of the creation of municipal unions in Poland in years 1990-2006.

Table 2. Municipal unions in Poland registered from 1990 till 31.03.2007

\begin{tabular}{|c|c|c|c|c|}
\hline Year & Unions established & Unions dissolved & $\begin{array}{l}\text { Number of unions in } \\
\text { the end of the year }\end{array}$ & $\begin{array}{c}\% \text { Of the total } \\
\text { registered unions }\end{array}$ \\
\hline 1990 & 1 & & 1 & 0.4 \\
\hline 1991 & 47 & & 48 & 17 \\
\hline 1992 & 31 & 1 & 78 & 28 \\
\hline 1993 & 25 & 1 & 102 & 36 \\
\hline 1994 & 23 & & 125 & 44 \\
\hline 1995 & 16 & & 141 & 50 \\
\hline 1996 & 13 & 4 & 150 & 53 \\
\hline 1997 & 15 & 5 & 160 & 57 \\
\hline 1998 & 15 & 2 & 173 & 62 \\
\hline 1999 & 5 & 3 & 175 & 62 \\
\hline 2000 & 18 & 1 & 192 & 68 \\
\hline 2001 & 23 & 5 & 210 & 75 \\
\hline 2002 & 17 & 2 & 225 & 80 \\
\hline 2003 & 9 & 5 & 229 & 81 \\
\hline 2004 & 13 & & 242 & 86 \\
\hline 2005 & 5 & 4 & 244 & 87 \\
\hline 2006 & 3 & 6 & 241 & 86 \\
\hline 2007(first quarter) & 1 & 2 & 240 & 85 \\
\hline Total & 281 & 41 & & \\
\hline
\end{tabular}

Source: National Register of Municipal Unions (status on 31.03.2007)[9] 
One should add that there is no requirement of formal dissolution of the union when it ceases its activity. Therefore among 240 unions formally existing on 31st March 2007 there are a few which actually finished their activity without formal dissolution or their activity is only symbolic.

One can conclude from the table however that, except from the end of the period, the number of newly established unions had highly outgrown the number of those dissolved. The sharp increase of the number of unions in the beginning of the investigated period is a natural consequence of the fact that earlier there was no democratic local self-government in Poland and the whole process started from zero-level. The one-year breakdown in the generally growing tendency in 1999 marks the date of the administrative reform in Poland and the introduction of district and regional self-governments. Further growth in subsequent years 2000-2005 provides the evidence that the reform did not make municipal unions redundant although their role has changed significantly.

Before the reform unions of municipalities were to some extent substituting missing medium levels of territorial self-governments i.e. districts and regions. After the reform they turn out to be still useful because some tasks of public administration required the territorial organization different than district or region.

A slight decrease of the number of unions appeared in the end of the investigated period. As it has appeared only in the year 2006 and in the first quarter of 2007 it is impossible to estimate now for sure whether it is only accidental breakdown or it reflects any long lasting tendency. It is likely that the number of unions will remain more or less stable for quite a long time due to the fact that they are already established where they have been needed and that certain balance has been reached between completed tasks, which make some unions redundant, and newly emerging problems, which require the establishment of new unions.

The size of unions varies very much. It ranges from two-member unions consisting of one town and of the neighbouring rural municipality to unions, which consist of a few tens of municipalities.

The distribution of unions according to size groups is presented in the next table.

As one can see in the table relatively small unions counting from 6 to 10 municipalities are the most common in Poland. The two first groups taken together i.e. unions consisting of $2-10$ municipalities constitute $76 \%$ of municipal unions existing in Poland on 31.03.2007. As regards the biggest unions there are only two unions, which have more than 30 member municipalities. The biggest one is The Union of Municipalities of Opole Silesia. It consists of 59 municipalities from Opole region in southwestern Poland. It was established in 1991 and its objectives have been formulated as: collecting, processing and transmission of information in the field of social and economic development, consulting, training and exchange of experience as well as promotion of member municipalities. The second biggest is The Union of Warmińsko-Mazurskie Municipalities. 37 municipalities from Warmińsko-Mazurskie region participate in this union. It was established in 1992 with the following objectives: promotion of tourism and ecology, protection of the environment and communication investments.[15].

Table 3. Municipal unions in Poland by size groups

\begin{tabular}{|l|c|c|c|c|c|c|c|}
\hline $\begin{array}{l}\text { Number of } \\
\text { member } \\
\text { municipalities }\end{array}$ & $2-5$ & $6-10$ & $11-20$ & $21-30$ & $31-40$ & $41-50$ & More than 50 \\
\hline $\begin{array}{l}\text { Number of } \\
\text { municipal } \\
\text { unions }\end{array}$ & 78 & 105 & 45 & 10 & 1 & 0 & 1 \\
\hline
\end{tabular}

Source: National Register of Municipal Unions (status on 31.03.2007)[9]

As far as territorial distribution of municipal unions they have been established across the country. Some of them are encompassed totally in one region whereas others are inter-regional unions i.e. they consist of municipalities from two or more neighbouring regions.

The distribution of municipal unions among regions of Poland is presented in the next table. 
Table 4. Municipal unions by regions

\begin{tabular}{|l|c|c|c|}
\hline \multicolumn{1}{|c|}{ Region } & $\begin{array}{c}\text { Population } \\
\text { in 2007 } \\
\text { (thousands) }\end{array}$ & $\begin{array}{c}\text { Number of municipalities } \\
\text { in 2005 }\end{array}$ & $\begin{array}{c}\text { Number of } \\
\text { municipal } \\
\text { unions }\end{array}$ \\
\hline Dolnośląskie & 2880.5 & 169 & 12 \\
\hline Kujawsko-Pomorskie & 2065.7 & 144 & 10 \\
\hline Lubelskie & 2170.6 & 213 & 11 \\
\hline Lubuskie & 1008.4 & 83 & 9 \\
\hline Lódzkie & 2560.9 & 177 & 22 \\
\hline Małopolskie & 3274.6 & 182 & 19 \\
\hline Mazowieckie & 5178.5 & 314 & 11 \\
\hline Opolskie & 1039.4 & 71 & 8 \\
\hline Podkarpackie & 2097.2 & 159 & 7 \\
\hline Podlaskie & 1194.5 & 118 & 15 \\
\hline Pomorskie & $2199.0^{\mathrm{a}}$ & 123 & 13 \\
\hline Śląskie & 4662.3 & 167 & 15 \\
\hline Świętokrzyskie & 1278.4 & 102 & 19 \\
\hline Warmińsko-Mazurskie & 1426.7 & 116 & 11 \\
\hline Wielkopolskie & 3380.2 & 226 & 8 \\
\hline Zachodniopomorskie & 1692.8 & 114 & \\
\hline
\end{tabular}

${ }^{a}$ year 2006

Source: National Statistical Office; National Register of Municipal Unions (Status on 31.03.2007)[9] [16]

One can conclude from the table that the number of unions in the region is roughly proportional to population and to the number of municipalities in the region.

Apart from unions, which consist of municipalities from a single region, there are unions formed by municipalities from two or more regions. These are shown in the next table.

Table 5. Inter-regional municipal unions in Poland

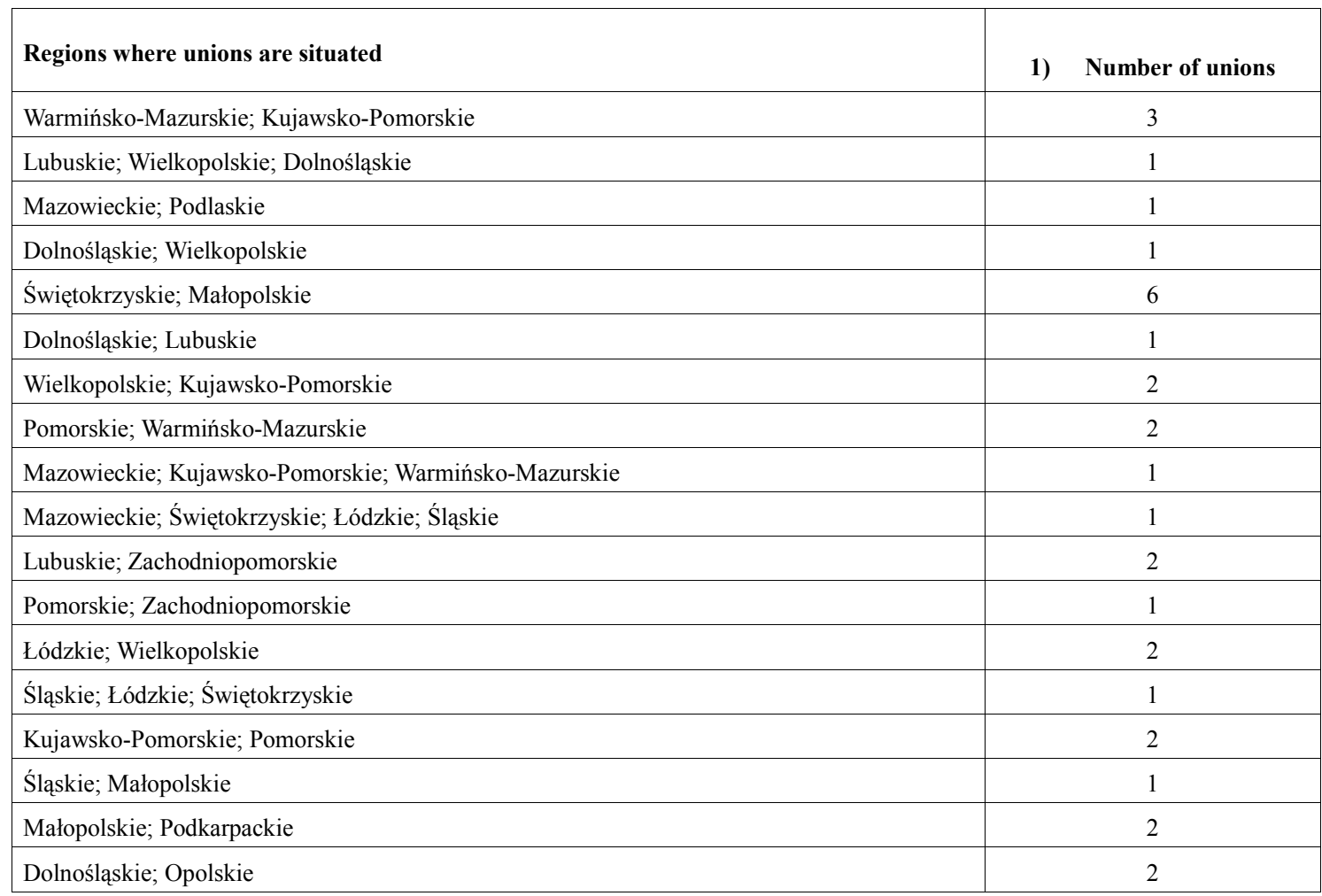




\begin{tabular}{|l|c|}
\hline Regions where unions are situated & 1) \\
\hline Lubelskie; Mazowieckie & Number of unions \\
\hline Świętokrzyskie; Mazowieckie & 1 \\
\hline Opolskie; Śląskie & 1 \\
\hline Lubelskie; Podkarpackie & 1 \\
\hline Total & 1 \\
\hline
\end{tabular}

Source: National Register of Municipal Unions (status on 31.03.2007)[15]

It is worthy to notice that only 7 inter-regional unions have been established after the administrative reform in 1999 whereas the remaining 29 were established earlier. It may indicate that inter-municipal links, which resulted in the creation of these unions, did not influence the new regional division of the country. Furthermore it indicates that there are still needs of inter-municipal collaboration in spatial extent different than administrative units and that there are other factors, which form the spatial shape of the union than administrative division. One of them may be the environment.

\section{Physical Features of the Environment as a Basis for Settlements Networking}

Interrelations between the physical environment and the settlement network, which have developed for centuries throughout the world, are also reflected in this particular form of settlements formal networking, which constitute municipal unions in Poland. Many of them have been formed in the spatial shape corresponding to natural regions taking also the name of the union from some features of the environment. Sometimes regardless of exact borders of the union some features of the environment only gave the name and are a sort of label of the union. There are also important practical reasons for the establishment of the union within some natural boundaries.

The occurrence of natural features of the environment in names of municipal unions in Poland is shown in the

\section{following table.}

The frequency of physical features of the environment in names of municipal unions can be to some extent explained by the very environment. Namely there is only one island in Poland big enough to host more than one municipality. So the Municipal Union of Wolin Island in Miedzyzdroje is the only Iceland union in Poland. Similarly there are few narrow peninsulas of specific type called in Polish "mierzeja". Only two of them are big enough to encompass a few municipalities but only on one of them gave the name to a municipal union.

Lakes and other water reservoirs as well as mountains and hills are more common in Poland therefore they appear more frequently in names of unions. Forest complexes and natural protected areas are quite numerous in Poland. However they are usually sparsely populated. They rather separate more densely populated areas. So relatively few local communities identify themselves with them.

Rivers are most common features of the environment used in names of unions for several reasons. The network of rivers is quite dense in Poland. So whatever is the area of the union there is usually at least one river, which crosses it. Quite often the name of the river is more convenient as the name of the union than the name of a city or town because it is more neutral i.e. it does not put any municipality on the first place. However there are also substantial reasons related to the activity of unions and to problems they cope with which cause that municipalities tend to cluster together in river valleys and catchment areas.

Table 6. Natural features of the environment in names of municipal unions

\begin{tabular}{|l|l|}
\hline \multicolumn{1}{|c|}{ Feature of the environment } & Number of unions \\
\hline Rivers and their catchment areas & 55 \\
\hline Lakes; water reservoirs, bays & 10 \\
\hline Forest complexes & 4 \\
\hline Natural protected areas & 2 \\
\hline Mountains and hills & 7 \\
\hline Islands & 1 \\
\hline Peninsulas & 1 \\
\hline Geological formations & 1 \\
\hline
\end{tabular}

Source: National Register of Municipal Unions (status on 31.03.2007)[15] 


\section{Environmental Issues among Statutory Activities of Municipal Unions}

Certainly, the role of the environment is not limited to providing label-features to the union. The place of environment-related tasks in the activity of the union is far more important. It is required by law that every union while formally registered must declare in its statute what are its main tasks. So the national register of municipal unions contains also the list of intended main fields of activity of each municipal union in Poland.

While looking through these lists one can easily notice that tasks of unions are formulated in many different ways. Sometimes under the heading "tasks of the union" there is a very detailed list of specific undertakings including not only the type of the undertaking but also more or less precisely defined place of its implementation. In other cases the same item contains only very general slogans, which imply that the actual tasks of the union will be formulated later during its functioning. Quite often there is something in the middle in the register i.e. relatively narrow specific activities and tasks follow very general introductory formulations.

However regardless of the way tasks are formulated it is evident that coping with environmental problems constitutes the bulk of statutory activities of municipal unions in Poland. Out of 240 municipal unions existing in Poland on 31.03.2007 only 43 did not have statutory tasks directly related to the environment. Furthermore many of this group have public transport as a priority tasks. So even though environmental concerns have not been explicitly written in their statutes they are indirectly involved in reducing environmental impact of traffic. It is also worthy to notice that the last union of these 43 has been registered on 11.07.2002 and that all unions registered after that date have some environmental tasks.

So 197 unions have some environmental tasks in their statutes. The frequency of the occurrence of the protection of the environment as well as more specific issues among tasks of municipal unions is shown in the table.

Table 7. Environmental issues among statutory tasks of municipal unions in Poland

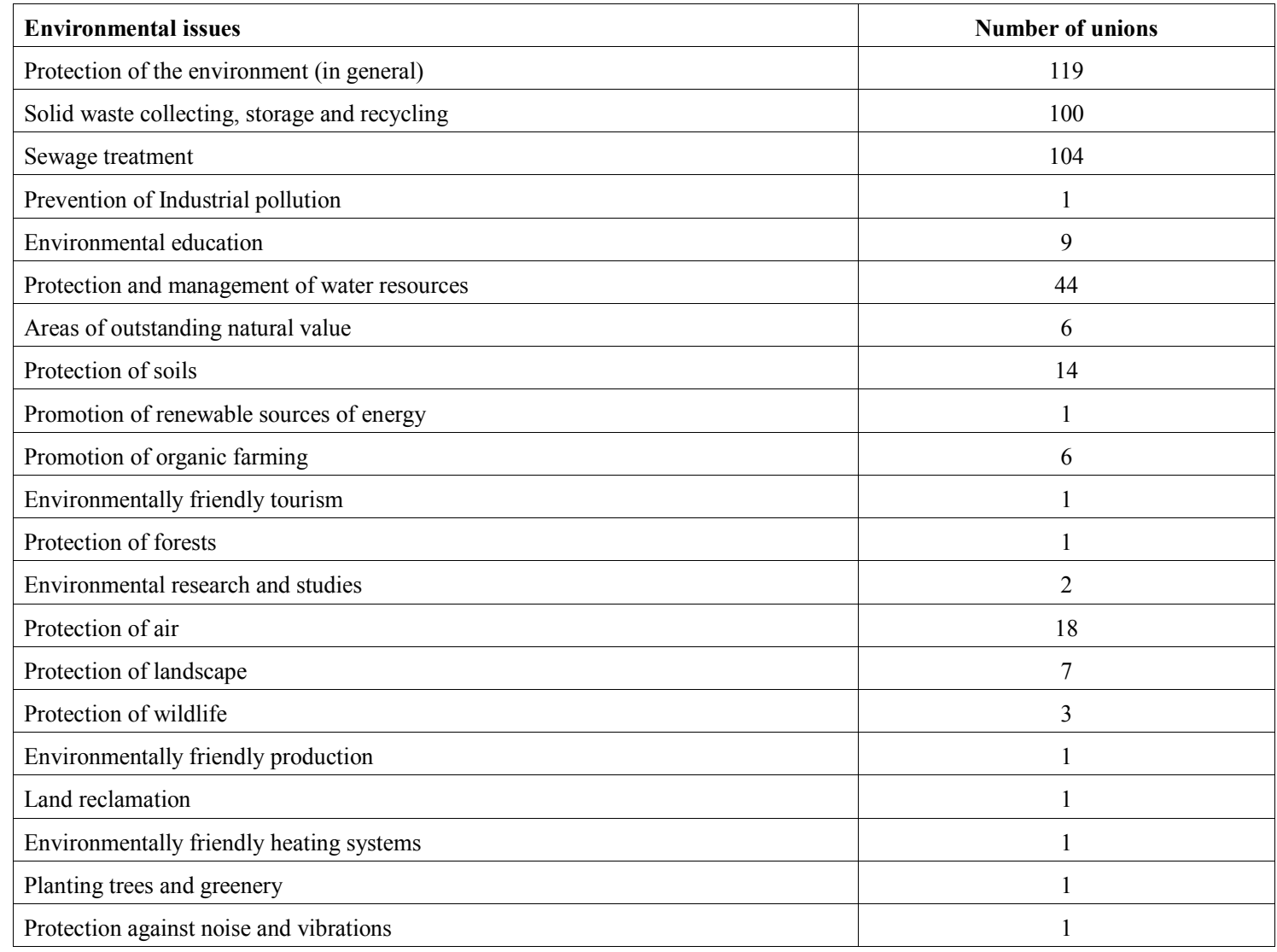

Source: National Register of Municipal Unions (status on 31.03.2007)[15] 
One should note that the above quoted figures do not constitute an exact balance due to the fact that every single union may have several of the above listed tasks inscribed in their statute and that tasks are not always precisely formulated. However they provide clear picture of priorities of municipal unions in the field of environment.

The protection of the environment appears most frequently in statutes of unions because it is the most general term. Sometimes it stands for the whole branch of activities and sometimes it is listed next to a few other specific environmental tasks.

Among more precisely defined tasks solid waste and sewage treatment are two issues, which occur most frequently in unions statutes. They are listed almost equal number of times and these numbers highly outgrow all other in the table. It reflects huge arrears of work in these fields as well urgency of these problems in Poland. The treatment of sewage as well as the management of solid household waste is both executive environmental tasks, which are in the competence of municipal self-governments. Simultaneously figures in the table indicate that these are problems, which require collaboration on larger scale to be solved. This happens mainly for physical (technical) and for economic reasons.

The most evident reason is the spatial structure of settlement in Poland. The large number of small towns and high percentage of rural population living in numerous villages with houses scattered across wide areas. For quite a long time rural settlements had no organized systems of sewage treatment or solid household waste management. The construction of water supply systems in rural areas, which started in 70ties and continued later resulted in huge amount of sewage discharged without treatment. Simultaneously the growth of income and the quality of life in villages caused that solid waste could not be utilized any more in traditional way i.e. partly burned in the fireplace, partly composted in the farm and partly recycled in the household. This way an acute gap in utilities appeared in Polish settlements. The work aimed at filling it in is currently under way. The construction of sewerage networks and sewage treatment plants for single municipality or for a single village would be too expensive. As it is more cost-effective to built sewerage systems for a few municipalities the construction of such systems became a common task of municipal unions. Furthermore it is technically reasonable to built sewerage networks, which carry sewage down to the treatment plant rather than pump it up. Therefore where possible networks follow the relief of the area and cover parts of the rivers catchment areas. No wonder then that so many unions cluster along river valleys.

As regards solid household waste the construction of safe place for its storage is not only expensive but also belongs to the most unwanted undertakings in any neighbourhood. So the construction of one such rubbish pit for several municipalities is not only more cost-effective but also reduces conflicts in local communities.

Bearing in mind the direct cause-effect relation between the quality of water resources and the provision of sewerage and solid waste management systems it is natural that the protection of water resources and water management is also a relatively frequent statutory task of municipal union.

Other environmental issues appear relatively rarely in statutes of unions. If they do it is usually either a response to particular environmental problems of the area (the protection of the air and soil) or it is an attempt to use some specific environmental assets for the development of the area (environmentally friendly tourism, organic farming, renewable sources of energy). The environmental consciousness of local communities is also reflected in the table above (e.g. environmental education). Other circumstances could also influence the environmental contents of unions' statutes. However their explanation would require a thorough investigation of every single case. Needless to say that it would be of little use for this paper and it is better to have a closer look at one more typical union and at its activity.

\section{Ecological Union of Municipalities of Koprzywianka River Basin - an Illustrative Example}

The following chapter is dedicated to one of many Polish municipal unions and to its activity in order to illustrate the above general characteristic of interrelated formal and physical networking of Polish settlements. Ecological Union of Municipalities of Koprzywianka River Basin is one of many unions, which group municipalities located in one river catchment area. Koprzywianka, the core river of the union is a small left-side tributary of Vistula River. It flows into Vistula at the point where the main river of Poland turns from northeast to north. The location of the river and the union is shown on the map 2.

The story of the union starts in 1992 when local governments in the area realized the need to join their forces in order to be able to solve common environmental problems. The idea of inter-municipal collaboration took the formal shape in 1994 when the union was registered. Initially there were 8 member municipalities: Baćkowice, Bogoria, Iwaniska, Klimontów, Koprzywnica, Łoniów, Samborzec and Sandomierz. In the year 2000 three more municipalities joined the union. Namely: Lipnik, Obrazów and Opatów. So now the union consists of 11 municipalities. Among them the city of Sandomierz is the only urban municipality with more than 25 thousand inhabitants. Koprzywnica and Opatów are mixed urban/rural municipalities as they consist of the town and a number of villages around it. Other members are purely rural municipalities. Together 107 thousand people live in the area of the union. Its total area amounts to $986 \mathrm{~km}^{2}$. The office of the union is located in Klimontów - one of rural member-municipalities. [7]

Registered statutory tasks of the union have been formulated as follows: 
Shaping and protection of the environment in the Koprzywianka catchment area by means of the protection of water, soil, air and landscape; tourism and recreation; ecological undertakings.

The land in the territory of the union is predominantly in agricultural use due to fertile soils. The mild climate is particularly favourable for cultivating fruits. Hence large areas covered with orchards. All municipalities of the union are from Świętokrzyskie region (województwo). As regards districts the area of the union covers parts of the following districts:

- Sandomierski district - city of Sandomierz and municipalities: Koprzywnica, Klimontów, Łoniów, Samborzec, Obrazów;

- Opatowski district - municipalities: Opatów, Baćkowice, Iwaniska, Lipnik,

- Staszowski district - municipality of Bogoria.
The union is associated in the National Association of Communal Municipal Unions. The location of all member unions of this association is shown on the map 2 .

The union has streamlined its environmental activities into three main fields:

- Formulation of common planning and strategic documents;

- The construction of common environmental utilities serving the whole union;

- Environmental education.

The first common environmental policy document was the Programme of Solid Waste Management approved in 2003. It was later amended in 2006. The programme contains the characteristic of the existing situation in the field of waste management as well as the description of tasks, which need to be performed in order to improve the situation. A separate chapter is dedicated to available sources of funding..

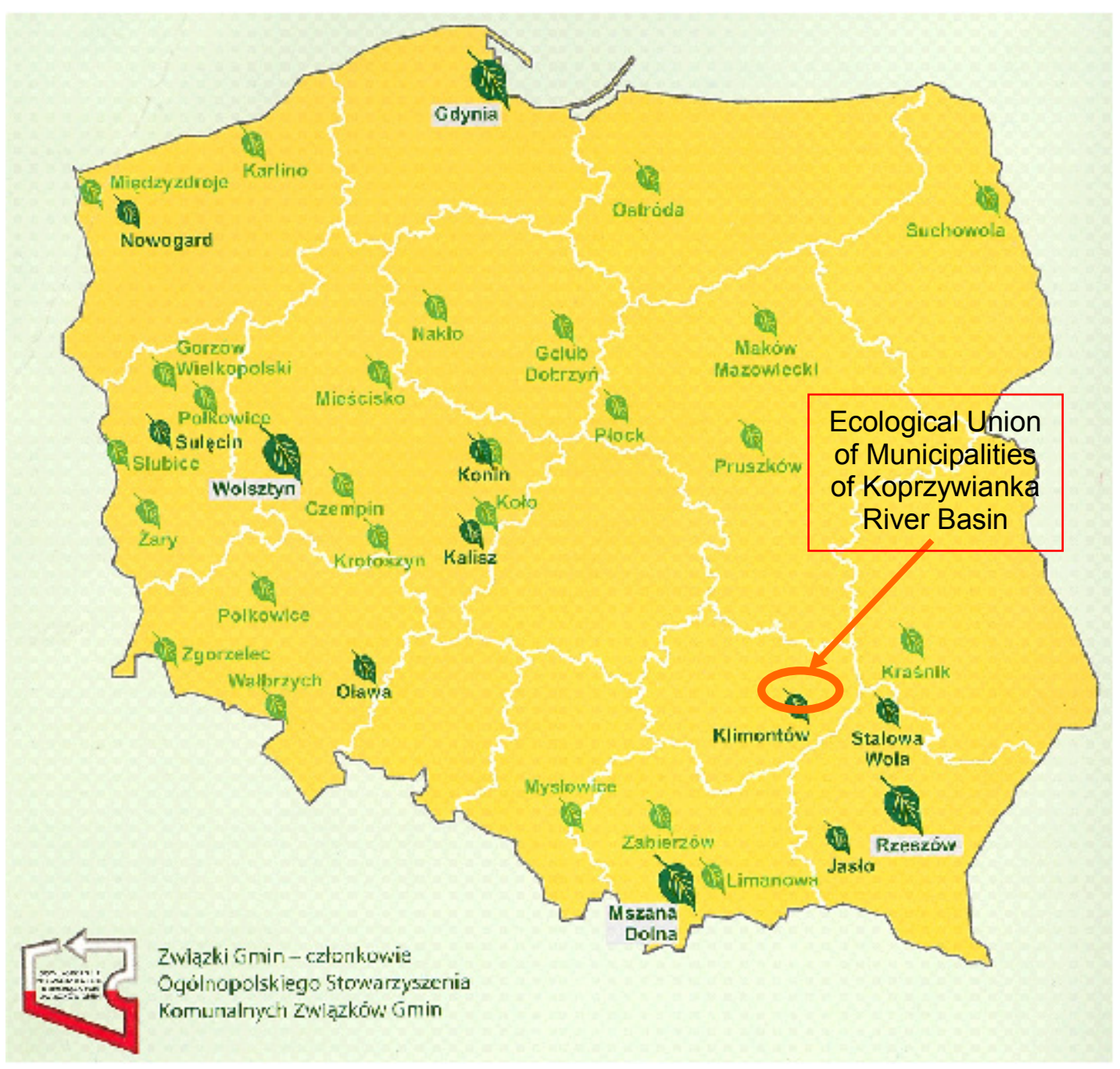

Map 2. Municipal Unions Associated in the National Association of Communal Municipal Unions Source: http://www.ezgdk.pl/wspolpraca.php [13] 
The common Environment Protection Programme was adopted in 2005. Apart from the characteristic of state of the environment in the union's area it contains a few chapters dedicated to activities aimed at the protection of particular components of the environment. Namely: forests, soils, mineral resources deposits, water resources and air. Furthermore it contains chapters dedicated to the protection against noise and against electromagnetic fields. One another chapter deals with the prevention of industrial breakdowns. There is also a short chapter about waste management. Similarly to the Waste Management Programme available sources of funding are widely described in the end of the programme.

Law requires both above programmes. The Waste Act from 2001 requires the elaboration of the waste management programmes whereas the Environmental Protection Law from 2001 requires Environment Protection Programmes from municipalities. Such programmes are also necessary while applying for funding.

As far as the construction of common utilities is concerned The Waste Utilization Plant in Janczyce is a flagship project and a subject of pride for the union. Its development process started in 2000 from the change of the local physical development plan enabling further steps towards the construction. The plant was finally launched in September 2005.

Funds for the construction of the plant were obtained from SAPARD Fund (50\%) and from the Foundation "EkoFundusz" (8\%). The loan from Regional Fund of Environment Protection and Water Management covered remaining $42 \%$.

The plant occupies the area of 8.5 hectares and it is equipped with a basic objects and installations necessary for the utilization of household solid waste. These basic objects are: sorting facility, composting facility and storage place. They are supplemented with transport, electric and administrative facilities. Four streams of household waste (mixed, biodegradable, package and problematic waste) are delivered to the plant from six systems. Each installation as well as the whole plant complies with the BAT principle.

As regards environmental education the activity of the union is targeted at pupils of primary and secondary schools from the area of the union. The union organizes yearly competitions between schools in collecting recyclable waste. Computers and computer accessories for schools are prizes in these competitions. Furthermore youth from the area takes part in the educational programme "Clean Vistula and Seaside Rivers" within this programme pupils take part in the environmental monitoring of the union's area.

Environmental education is also a subject of collaboration between municipal unions associated in the above-mentioned National Association of Communal Municipal Unions. Each union in turn organizes educational foot trips in areas of outstanding natural beauty enabling the youth to learn the nature directly in the field.

\section{Conclusions}

The above paper has been written on the basis of literature and on the basis of publicly available statistics and general knowledge of the subject. Therefore the following conclusions should be considered preliminary rather than final and may be verified and supplemented on the basis of more thorough research in the future.

As far as the first research question is concerned one can conclude that the 1999 administrative reform in Poland did not make municipal unions redundant. Although two intermediate levels of the territorial self-government were introduced municipalities still exercise the opportunity to act within the union in order to perform their statutory tasks. The most likely reason for it is the following difference between the unit of territorial administration and the union of municipalities. The first one was established on the basis of an administrative decision made on the national level and it performs general tasks of the territorial administration. The second one was established on the basis of voluntary decision of each member-municipality in order to perform only some selected tasks that are within the competence of the municipality or of the other unit of territorial administration but the union has a better chance to perform them more effectively. This way units of administration and unions of municipalities rather supplement than double each other.

As regards the second research question it is evident that environmental problems constitute the most common reason for the establishment of municipal unions in Poland and environment-related tasks are the most frequent among statutory tasks of these unions. Consequently the protection of water resource either expressed directly or under the heading of sewage treatment is the most frequent among environmental tasks of unions. It is mainly the result of multi-annual arrears of work in domains of the construction of sewerage systems and in household waste management. The domination of water related problems is also the main reason why the spatial shape of municipal unions tends to follow river catchment areas.

The importance of the protection of water resources in the activity of unions of municipalities in Poland confirms the widely known role of water management in the development of human settlements. So far, however, researchers and policy makers have focused their attention either on arid zones [4] and on the prevention of desertification [3] or on floods and other water related risks [7 ]. Comparatively to disasters caused by the scarcity or by the surplus of water the activity of the union of municipalities is far less visible phenomena. The latter however, has a good chance to prevent the first if well done.

For the sake of the local environment formal networking of urban and rural settlements in the form of municipal union can be effectively converted into their physical networking by means of common environmental facilities if the political will and environmental consciousness as well as adequate motivation and determination among members of municipal 
union exists.

\section{REFERENCES}

[1] Głowacki W. Regionalization in Poland in: Marcou G.(eds) Bucek J., Głowacki W., Kalman J, Petkevicius A. Regionalization for Development and Accession to European Union a Comparative Perspective LGI OSI Budapest 2002.

[2] Górski M. Zadania z zakresu ochrony środowiska (Tasks in the domain of environmental protection) in Nowe Prawo Samorządowe komentarze (New self-governmental law comments)

[3] Laureano P. The Water Atlas: Traditional knowledge to combat desertification, Unesco / Bollati Boringhieri editore s.r.l. Paris/Turin $2001 \quad$ Download from: https://www.box.com/s/xroo4hsq2bl190vjuu4x

[4] Mays L. (eds) Integrated Urban Water Management: Arid and Semi-arid Regions UNESCO / Taylor \& Francis Leiden 2009

[5] Moreno A. M. (eds) Local Government in the Member States of the European Union: A comparative Legal Perspective INAP, Madrid 2012

[6] Naess P. Saglie I. Glowacki W. Dunin-Woyseth H. Environmental Considerations in Physical Planning Under Different Conditions: A Comparison of a Polish and a Norwegian Municipality Scandinavian Housing \& Planning Research 15, 1998

[7] Prenger-Berninghoff K., Cortes V. J., Sprague T., Aye Z. C., Greiving S., Głowacki W., and Sterlacchini S. The connection between long-term and short-term risk management strategies for flood and landslide hazards: examples from land-use planning and emergency management in four European case studies Nat. Hazards
Earth Syst. Sci., 14, 2014

[8] Sjoberg, O. Cases onto themselves? Theory and research on ex-socialist urban environments Geografie, 119, No. 4, 2014

[9] Konstytucja Rzeczpospolitej Polskiej (Constitution of The Republic of Poland) Dz.U. 97.78.483

[10] Ustawa z dnia 27 kwietnia 2001 Prawo Ochrony Środowiska (Environmental Protection Law) Dz.U. 01.62.627 with later amendments.

[11] Ustawa $z$ dnia 8 marca 1990 os amorządzie gminnym (The Act on Municipal Self-government) Dz.U.01.142.1591 with later amendments.

[12] Rozporządzenie Rady Ministrów z dnia 9 listopada 2004 w sprawie określenia rodzajów przedsięwzięć mogących znacząco oddziaływać na środowisko oraz szczegółowych uwarunkowań związanych z kwalifikowaniem przedsięwzięcia do sporządzenia raportu o oddziaływaniu na środowisko (on categories of undertakings which may significantly affect the environment and on detailed conditions related to qualifying the undertaking for the preparation of EIA report) Dz.U. 04.06.08 with later amendments

[13] http://www.ezgdk.pl - Ecological Union of Municipalities of Koprzywianka River Basin

[14] http://www.gugik.gov.pl - Central Office for Geodesy and Cartography

[15] http://www2.mswia.gov.pl - Ministry of Interior and Administration

[16] http://www.stat.gov.pl - Central Statistical Office and its regional branches 